\title{
Kejadian Anemia Berdasarkan Status Gizi, Pengetahuan dan Pola Minum Teh pada Remaja Putri di Pondok Pesantren
}

\author{
Anemia Event Based on Nutrition Status, Knowledge and \\ Pattern of Drinking Tea In Princess Adolescents In Islamic Boarding Schools
}

Riyanto Riyanto $^{1, \bowtie}$, Gangsar Indah Lestari ${ }^{2}$

${ }^{1}$ Jurusan Kebidanan, Politeknik Kesehatan Tanjung Karang, Indonesia

${ }^{凶}$ Corresponding author: nsriyanto70@yahoo.com

Kata kunci
Anemia pada remaja putri,
Indeks Masa Tubuh
(IMT),
Pengetahuan.

Keyword

Anemia in young women, Body Mass Index (BMI), knowledge.

\begin{abstract}
Abstrak
Latar belakang: Anemia pada remaja putri merupakan masalah yang umum dijumpai terutama di negara-negara berkembang. Tujuan: Tujuan penelitian untuk mengetahui hubungan faktor status gizi, pengetahuan dan pola minum teh dengan kejadian anemia pada remaja putri. Metode: Rancangan penelitian menggunakan studi cross sectional dilakukan pada bulan November 2016. Populasi penelitian adalah remaja putri di Pondok Pesantren Tuma'ninah Yasin kota Metro dengan sampel berjumlah 69 yang diambil dengan teknik total populasi. Pengumpulan data dilakukan dengan pemeriksaan darah tepi, pemeriksaan tinggi badan, berat badan dan menyebarkan kuesioner. Analisis data dilakukan secara bertahap, yaitu analisis univariat dan analisis bivariat menggunakan uji chi square. Hasil: Hasil analisis memperlihatkan kejadian anemia pada remaja berjumlah $68,1 \%$. Faktor-faktor risiko yang meningkatkan kejadian anemia pada remaja putria, yaitu status gizi atau IMT $(\mathrm{p}=0,32$; $P O R=3,096)$ dan pengetahuan $(p=0,050 ; P O R=3,083)$. Simpulan: Faktor status gizi yang kurang atau berlebih dan pengetahuan kurang meningkatkan kejadian anemia pada remaja putri. Pentingnya upaya pendidikan kesehatan tentang anemia kepada remaja putri untuk meningkatkan pengetahuan dan dan mengkonsumsi tablet $\mathrm{Fe}$ khususnya remaja putri baik dengan status gizi baik maupun kurang.
\end{abstract}

\begin{abstract}
Background: Anemia in adolescent girls is a common problem especially in developing countries. Purpose: The purpose of this study was to determine the relationship between factors of nutritional status, knowledge and patterns of drinking tea with the incidence of anemia in young women. Methods: The study design using a cross sectional study was carried out in November 2016. The study population was young women in Tuma'ninah Yasin Islamic Boarding School in Metro City with a total sample of 69 taken with total population techniques. Data collection was done by examining peripheral blood, height, weight and distributing questionnaires. Data analysis was carried out in stages, namely univariate analysis and bivariate analysis using the chi square test. Results: The results of the analysis showed the incidence of anemia in adolescents amounted to $68.1 \%$. Risk factors that increased the incidence of anemia in adolescent boys, namely nutritional status or BMI $(p=0.32 ; P O R=$ 3.096) and knowledge $(p=0.050 ;$ POR = 3.083). Conclusions: Factors of poor or excessive nutritional status and lack of knowledge increase the incidence of anemia in adolescent girls. The importance of health education efforts about anemia to young women to increase knowledge and consume Fe tablets, especially young women with good and poor nutritional status.
\end{abstract}

Copyright () 2017 Jurnal Kesehatan Metro Sai Wawai. All rights reserved. 


\section{Pendahuluan}

Anemia merupakan masalah kesehatan yang paling sering dijumpai dinegara-negara maju maupun berkembang termasuk Indonesia (WHO, 2008). Anemia umumnya dijumpai pada golongan rawan gizi yaitu ibu hamil, menyusui, balita, anak sekolah dan remaja. Anemia pada remaja putri merupakan masalah yang umum dijumpai terutama dinegara-negara berkembang (WHO, 2008).

Masalah kekurangan gizi, termasuk anemia jika tidak diatasi dapat menyebabkan gangguan pertumbuhan fisik dan perkembangan kecerdasan terganggu, menurunnya produktifitas kerja dan daya tahan tubuh yang berakibat meningkatnya angka kesakitan dan kematian (Depkes RI, 2001). Anemia pada remaja putri dapat mengakibatkan masalah periode puncak tumbuh kembang yang kedua (Arisman, 2010), kebugaran tubuh berkurang, lambat menerima dan memproses informasi, gangguan memori, hingga lambatnya pembelajaran. Keadaan ini akan mengarah pada rendahnya kecerdasan dan prestasi belajar serta sulit memecahkan masalah (Soejatmiko, 2010). Dampak lain, anemia pada remaja akan memberikan kontribusi negatif atau masalah pada masa kehamilan yang akan datang, diantaranya adalah dapat melahirkan dengan bayi berat lahir rendah, asfiksia, bahkan pada bayi (Dieny, 2014). Selain itu, bila hamil berisiko mengalami perdarahan waktu melahirkan sebesar $40 \%$, sedangkan perdarahan merupakan penyebab pertama kematianibu di Indonesia (Depkes RI, 2001).

Menurut survei WHO tahun 2000 memperoleh hasil dari jumlah penduduk di dunia diantaranya 52 dari 100 remaja putri dinyatakan anemia (http://www.gizinet.com). Prevalensi anemia kekurangan zat besi di negara berkembang jauh lebih tinggi dari negara maju, yaitu masing-masing $36 \%$ dan $8 \%$. Dibeberapa negara prevalensi anemia defisiensi besi pada remaja putri yaitu: $82,5 \%$ di Banglades, $23 \%$ di China, dan 42,2\% di Filipina dan terdapat 74,7\% di India (Demaeyer, 2003 \& Kotecha, 2000 dalam Isniati, 2007).

Penanganan masalah anemia pada remaja atau wanita usia subur sudah dilakukan, namun prevalensi anemia masih tergolong tinggi walaupun sudah ada kecenderungan penurunan. Hasil SKRT tahun 2004 menyatakan prevalensi anemia gizi pada remaja putri (10-18 tahun) 57,1\%. Angka tersebut yang tertinggi dibandingkan kelompok lain pada balita 40,5\%, ibu hamil 50,1\%, dan ibu nifas 45,1\%. Hasil riset kesehatan dasar (Riskesdas) tahun 2007 ditemukan kejadian anemia 19,7 pada perempuan dewasa ( $\geq 15$ tahun) (Badan Litbangkes RI, 2008). Sedangkan, hasil Riskesdas tahun 2013 terdapat penurunan prevalensi anemia remaja (15-24 tahun) menjadi 18,4\% (Badan Litbangkes RI, 2013). Walaupun sudah turun, namun prevalensi anemia remaja putri tergolong menjadi masalah kesehatan, karena besarnya $>15 \%$.

Di Provinsi Lampung, prevalensi anemia pada perempuan dewasa ( $\geq 15$ tahun) menurut Riskesdas 2007 tergolong tinggi di atas angka nasional, yaitu mencapai 25,9\% (Badan Litbangkes RI, 2008). Hasil penelitian di lima SMA Negeri di kota Metro tahun 2010 ditemukan sebesar 24,1\% dari 224 responden remaja putri mengalami anemia (Weliyati \& Riyanto, 2012). Hasil survei Dinkes kota Metro (2015) melaporkan prevalensi anemia remaja usia 15-19 tahun berjumlah 6,7\%, lebih tinggi $(18,4 \%)$ dibandingkan dengan hasil Riskesdas 2013 untuk Provinsi Lampung kejadian anemia perempuan usia 15-24 tahun.

Studi pendahuluan untuk mengetahui kejadian anemia remaja dilakukan di tiga Pondok Pesantren yang menyelenggarakan pendidikan Madrasah Aliyah (MA). Hasil pemeriksaan haemoglobin terhadap 10 Santri diperoleh hasil kejadian anemia berjumlah 70\% (7 santri) di Pondok Tuma'ninah Yasin kota Metro, 70\% (7 santri) di Pondok Darul 'Amal kota Metro dan 50\% (5 santri) di Pondok AlMuhsin kota Metro. Kejadian anemia pada remaja putri di Pondok Pesantren tersebut lebih tinggi dibandingkan dengan prevalensi anemia remaja di kota Metro. Masalah kejadian anemia remaja tersebut, mendasari penelitian ini dengan tujuan mengetahui beberapa faktor yang berhubungan dengan kejadian anemia pada remaja putri di Pondok Pesantren Tuma’ninah Yasin Kota Metro. 


\section{Metode}

Penelitian ini merupakan penelitian analitik kuantitatif. Rancangan studi menggunakan studi potong lintang (cross sectional study) yang dilaksanakan pada bulan November 2016. Populasi dalam penelitian ini adalah semua remaja putri di Pondok Pesantren Tuma'ninah Yasin kota Metro tahun 2016 yang berjumlah 97 orang. Jumlah sampel penelitian dengan mempertimbangkan jumlah populasi yang relatif sedikit, maka sampel penelitian menggunakan total populasi dan yang memenuhi syarat berjumlah 69 orang. Sampel penelitian adalah perwakilan populasi yang memenuhi syarat untuk dimasukkan dalam analisis penelitian sesuai kriteria inklusi dan eksklusi penelitian. Kriteria inksklusi penelitian adalah remaja putri di Pondok Pesantren Tuma'ninah Yasin kota Metro tahun 2016. Kriteria eksklusi penelitian, yaitu responden yang saat dilakukan penelitian belum mengalami menstruasi.

Variabel dependent penelitian adalah kejadian kejadian anemia. Sedangkan, variabel independent, yaitu status gizi (IMT), pengetahuan dan pola minum teh. Pengumpulan data menggunakan jenis data primer. Teknik pengumpulan data terhadap variabel penelitian akan dilakukan menggunakan teknik observasi dan menyebarkan angket kepada responden. Observasi dilakukan untuk mengumpulkan data variabel penelitian kejadian anemia dengan pemeriksaan darah perifer dan IMT dengan mengukur berat badan dan tinggi badan. Sedangkan, menyebarkan angket menggunakan instrumen penelitian dalam bentuk kuesioner untuk mengumpulkan data variabel penelitian: pengetahuan dan pola minum teh. Analisis data dilakukan secara bertahap, yaitu analisis univariat dan analisis bivariat menggunakan uji chi square.

\section{Hasil}

\section{Karakteristik Responden}

Karakteristik responden memperlihatkan kejadian anemia pada remaja putri di Pondok Pesantren Tuma'ninah Yassin berjumlah 68,1\%. Remaja putri dengan dengn status gizi (IMT) kurus atau gemuk berjumlah $37,7 \%$, pengetahuan kurang 49 orang (71\%), dan minum teh setelah makan hanya $15,9 \%$.

\section{Analisis Bivariat}

Analisis bivariat untuk membuktikan beberapa faktor risiko yang berhubungan dengan kejadian anemia pada remaja putri. Analisis bivariat menggunakan uji chi square. Hasil analisis pada tabel 1 menunjukkan ada hubungan signifikan antara status gizi (IMT) dengan kejadian anemia remaja putri (p value 0,032) dan remaja putri dengan status gizi (IMT) kurus atau berlebih/gemuk berisiko 3,96 kali untuk menderita anemia dibandingkan dengan remaja putri yang status gizinya baik/cukup (POR=3,960 (CI 95\% 1,163-13,488). Tabel 2 menunjukkan ada hubungan yang signifikan antara pengetahuan dengan kejadian Anemia Remaja Putri ( $\mathrm{p}$ value 0,050. Remaja putri dengan pengetehuan kurang berisiko 3,083 kali mengalami kejadian anemia dibandingkan remaja putri yang memiliki pengetahuan cukup (95\% CI: 1,035-9,188). Sedangkan, hasil analisis pada tabel 3 menunjukkan tidak ada hubungan minum teh setelah makan dengan kejadian anemia pada remaja putri ( $\mathrm{p}$ value 0,157 ).

Tabel 1

Hubungan Status Gizi (IMT) dengan Kejadian Anemia pada Remaja Putri di Pondok Pesantren Tuma'ninah Yasin Kota Metro

\begin{tabular}{lcccccccc}
\hline \multirow{2}{*}{ Status Gizi (IMT) } & \multicolumn{4}{c}{ Anemia Remaja Putri } & \multicolumn{2}{c}{ Total } & \multirow{2}{*}{ P Value } & POR \\
\cline { 2 - 7 } & Ya & \% & Tidak & \% & Jumlah & \% & & \\
\hline Kurus/Gemuk & 22 & 84,6 & 4 & 15,4 & 26 & 100 & & 3,096 \\
Baik/Cukup & 25 & 58,1 & 18 & 41,9 & 43 & 100 & 0,032 & $(1,163-$ \\
Jumlah & 47 & 68,1 & 22 & 31,9 & 69 & 100 & & $13,488)$ \\
\hline
\end{tabular}


Tabel 2

Hubungan Pengetahuan dengan Kejadian Anemia pada Remaja Putri di Pondok Pesantren Tuma'ninah Yasin Kota Metro

\begin{tabular}{lcccccccc}
\hline \multirow{2}{*}{ Pengetahuan } & \multicolumn{3}{c}{ Anemia Remaja Putri } & \multicolumn{3}{c}{ Total } & \multirow{2}{*}{ P Value } & POR \\
\cline { 2 - 8 } & Ya & \% & Tdk & \% & Jumlah & \% & & 3,083 \\
\hline Kurang & 37 & 75,5 & 12 & 24,5 & 49 & 100 & & 0.050 \\
Baik & 10 & 50,0 & 10 & 50,0 & 20 & 100 & 0,050 & $(1,035-$ \\
Jumlah & 47 & 68,1 & 22 & 31,9 & 69 & 100 & & $9,188)$ \\
\hline
\end{tabular}

Tabel 3

Hubungan Pola Minum Teh dengan Kejadian Anemia pada Remaja Putri di Pondok Pesantren Tuma'ninah Yasin Kota Metro

\begin{tabular}{lcccccccc}
\hline \multirow{2}{*}{ MinumTeh } & \multicolumn{9}{c}{ Anemia Remaja Putri } & \multicolumn{2}{c}{ Total } & \multirow{2}{*}{ P Value } & POR \\
\cline { 2 - 7 } & Ya & \% & Tidak & \% & Jumlah & \% & & 5,676 \\
\hline Minum teh & 10 & 90,9 & 1 & 9,1 & 11 & 100 & & 0,157 \\
Tidak & 37 & 63,8 & 21 & 36,2 & 58 & 100 & $0,678-$ \\
Jumlah & 47 & 68,1 & 22 & 31,9 & 69 & 100 & & $47,485)$ \\
\hline
\end{tabular}

\section{Pembahasan}

\section{Kejadian anemia remaja putri}

Hasil penelitian menunjukkan prevalensi anemia pada remaja putri yang dilakukan di Pondok Pesantren Tuma'ninah Yasin kota Metro berjumlah $68,1 \%$ orang dari 69 orang. Prevalensi ini cenderung lebih tinggi dibandingkan dengan penelitian lainnya. Di Provinsi Lampung, prevalensi anemia pada perempuandewasa ( $\geq 15$ tahun) menurut Riskesdas 2007 berjumlah 25,9\% (Badan Litbangkes RI, 2008). Hasil penelitian oleh Weliyati dan Riyanto di lima SMA Negeri di kota Metro tahun 2010 sebesar $24,1 \%$ dari 224 responden remaja putri mengalami anemia (Weliyati \& Riyanto, 2012) dan Data Dinas Kesehatan kota Metro (2015) melaporkan prevalensi anemia remaja usia 15-19 tahun berjumlah $67 \%$. Perlunya upaya penurunan dan pencegahan kejadian anemia remaja putri dengan memberikan edukasi dan pemberian asupan tablet Fe.

\section{Hubungan status gizi (IMT) dengan kejadian anemia pada remaja putri}

Hasil penelitian memperlihatkan ada hubungan signifikan antara status gizi (IMT) dengan kejadian anemia remaja putri $(\mathrm{p}=0,032)$. Remaja putri dengan status gizi (IMT) kurus atau berlebih/gemuk berisiko 3,083 kali untuk menderita anemia dibandingkan dengan remaja putri yang status gizinya baik/cukup (CI 95\%: 1,035-9,188). Terdapat 22 orang $(84,6 \%)$ dari 26 remaja putri dengan status gizi (IMT) kurus atau berlebih/gemuk mengalami anemia. Sedangkan diantara diantara remaja putri dengan status gizi (IMT) kurus atau berlebih/gemuk tidak mengalami anemia berjumlah 4 orang $(15,4 \%)$.

Hasil penelitian ini sesuai dengan penelitian sebelumnya oleh Gunatmaningsih (2007) di SMA Negeri Jatibarang Brebes bahwa ada hubungan antara status gizi dengan kejadian anemia defisiensi besi $(\mathrm{p}=0,002$ dan $\mathrm{OR}=2,175)$. Penelitian lain di SMA sekota Metro oleh Weliyati dan Riyanto (2010) memperoleh hasil ada hubungan yang bermakna antara status gizi (IMT) dengan kejadian anemia ( $\mathrm{p}-=$ 0,018) (Weliyati \& Riyanto, 2012).

Status gizi kurang berperan dalam mempengaruhi pertumbuhan dan fungsi organ reproduksi yang berdampak terhadap siklus menstruasi tidak normal. Siklus menstruasi yang pendek $(<21$ hari) berhubungan dengan kejadian anemia pada remaja putri, terlebih usia $<19$ tahun. Wanita dengan usia subur diperlukan status gizi yang baik dengan mengkonsumsi makanan seimbang, karena sangat dibutuhkan pada saat menstruasi terutama pada fase luteal. Selama proses menstruasi fase luteal terjadi peningkatan kebutuhan zat gizi yang cukup, sehingga siklus menstruasi dapat normal. Selain itu, status gizi berlebih atau obesitas pada wanita, juga ditemukan mengalami gangguan siklus menstruasi. Hal ini 
berkaitan dengan jumlah jaringan lemak tubuh. Jaringan lemak tidak hanya sebagai penyimpanan lemak, tetapi juga sebagai kelenjar endokrin penghasil hormon dan sel target untuk berbgai hormon, diantaranya hormon reproduksi (Dieny, 2014). Status gizi sangat terkait dengan asupan makanan. Kemungkinan status gizi kurang pada remaja putri pada responden, karena makanan sehari-hari yang diberikan oleh Pondok tidak selalu memenuhi menu seimbang. Selain itu, remaja putri cenderung tidak mampu memenuhi asupan gizi tambahan di Pondok yang mereka sekolah dengan biaya gratis. Hal ini dapat berakibat status gizi kurang pada sebagain responden.

Gangguan siklus menstruasi akibat obesitas atau status gizi kurang berhubungan dengan kejadian anemia pada remaja. Untuk itu, remaja dianjurkan mengkonsumsi tablet mengandung zat besi atau makanan yang mengandung zat besi seperti hati bayam dan sebagainya. Demi kesuksesan keadaan gizi remaja harus mendapatkan tambahan protein, mineral, vitamin dan energi. Setiap aktivitas memerlukan energi maka banyak aktivitas yang dilakukan maka banyak energi yang diperlukan. Makanan yang dikonsumsi oleh remaja harus memiliki jumlah kalori dan zat gizi yang sesuai atau seimbang dengan kebutuhan seperti karbohidrat, lemak, protein, vitamin, mineral, serat dan air sehingga satus gizinya dapat tercukupi dan tidak mengalami anemia.

\section{Hubungan pengetahuan dengan kejadian anemia pada remaja putri}

Hasil analisis memperlihatkan terdapat hubungan yang signifikan antara pengetahuan dengan kejadian anemia remaja putri $(\mathrm{p}=0,050)$. Remaja putri dengan pengetehuan kurang berisiko 3,083 kali mengalami kejadian anemia dibandingkan remaja putri yang memiliki pengetahuan cukup $(95 \% \mathrm{CI}$ : $1,035-9,188)$. Terdapat 37 orang $(75,5 \%)$ dari 49 remaja putri dengan pengetahuan kurang mengalami anemia. Sedangkan, diantara diantara remaja putri dengan pengetahuan kurang tidak mengalami anemia berjumlah 12 orang $(24,5 \%)$.

Hasil penelitian ini sesuai dengan penelitian sebelumnya oleh Wahyuni, dkk. Di SMA Takhasus Al-Qur'an Kalibeber Wonosobo tahun 2015 diperoleh ada hubungan yang bermakna antara pengetahuan dengan kejadian anemia pada Siswi di SMA Takhassus Al-Qur'an Kalibeber Wonosobo $(p=0,001)$ dan penelitian oleh Martini di MAN 1 Lampung Timur tahun 2015 menyimpulkan bahwa ada hubungan antara pengetahuan dengan kejadian anemia ( $\mathrm{p}=0,048$; OR=2,331; 95\% CI:1,080-5,027) (Martini, 2015).

Pengetahuan merupakan domain yang sangat penting dalam membentuk prilaku atau tindakan seseorang (Notoatmodjo, 2010). Salah satu faktor yang mempengaruhi anemia adalah pengetahuan tentang anemia. Pengetahuan remaja putri yang kurang tentang anemia merupakan faktor resiko yang dapat menyebabkan kejadian anemia karena pengetahuan seseorang mempengaruhi perilaku termasuk kebiasaan mengkonsumsi makanan dan pola hidup (Departemen Gizi Kesehatan Masyarakat, 2009). Pengetahuan seseorang dapat mempengaruhi terjadinya anemia, karena pengetahuan dapat mempengaruhi perilakunya termasuk pola hidup dan kebiasaan makan. Kurangnya pengetahuan tentang anemia, tanda-tanda, dampak, dan pencegahannya mengakibatkan remaja mengonsumsi makanan yang kandungan zat besinya sedikit sehingga asupan zat besi yang dibutuhkan remaja tidak terpenuhi.

Pengetahuan yang kurang dapat terlihat dari sebagain responden ada yang jawabannya tidak ada yang benar dan belum pernah mendapatkan informasi atau penyuluhan tentang anemia, khususnya responden dari MTs. Perlunya, upaya peningkatan pengetahuan tentang anemia dan cara pencegahannya pada remaja putri.

\section{Hubungan minum teh dengan kejadian anemia pada remaja putri}

Hasil penelitian memperlihatkan tidakada hubungan minum teh setelah makan dengan kejadian anemia pada remaja putri $(\mathrm{p}=0,157 ; \mathrm{POR}=5,676 ; 95 \%$ CI: $0,678-47,485)$. Terdapat 10 orang $(90,9 \%)$ 
dari 11 remaja putri yang minum teh setelah makan mengalami anemia. Sedangkan, diantara-diantara remaja putri dengan minum teh tidak mengalami anemia berjumlah 1 orang $(9,1 \%)$.

Salah satu masalah utama penyebab anemia adalah penyerapan tidak adekuat zat besi (Arisman, 2010). Penyerapan tidak adekuat zat besi karena dihambat oleh zat-zat seperti: zat tannin yang terdapat dalam teh. Selain itu, kopi, zat fosfitin yang terdapat dalam kuning telur dan protein kedelai, zat fitat dan fosfat yang banyak terdapat pada serealia, serta beberapa jenis serat makanan karena bersama zat besi membentuk senyawa yang tidak larut dalam air sehingga tidak dapat diabsorsi (Wirakusumah, 1999). Penyerapan yang tidak adekuat juga dipengaruhi oleh kurangnya asupan vitamin $C$ dan protein hewani yang terdapat dalam daging sapi, ayam dan ikan yang mengandung asam amino pengikat $\mathrm{Fe}$ yang membantu penyerapan zat besi.

Hasil penelitian tidak sesuai dengan teori di atas dan hasil penelitian sebelumnya. Penelitian oleh Wahyuni, dkk. di SMA Takhasus Al-Qur'an Kalibeber Wonosobo tahun 2015 menyimpulkan bahwa ada hubungan yang bermakna antara perilaku minum Teh atau kopi dengan kejadian anemia pada Siswi di SMA Takhassus Al-Qur'an Kalibeber Wonosobo ( $\mathrm{p}=0,029)$.

Perbedaan hasil penelitian, yaitu tidak ada hubungan antara pola minum teh dengan kejadian anemia pada remaja, kemungkinan karena jumlah sampel yang tidak memenuhi syarat minimal penelitian. Sampel penelitian diambil dengan teknik total populasi karena jumlah responden yang terbatas. Jumlah sampel yang kurang terlihat dari heterogen responden yang minum teh sangat sedikit, sehingga terdapat kelemahan ketika dianalisis.

\section{Simpulan dan Saran}

Prevalensi anemia remaja putri diperoleh berjumlah 68,1\% (47 orang) dari 69 responden. Faktor risiko yang meningkatkan dengan kejadian anemia remaja putri adalah faktor status gizi (IMT) kuranr atau berlebih dan pengetahuan dengan kejadian anemia pada remaja putri. Status gizi (IMT) kurang atau berlebih/gemuk berisiko meningkatkan 3,96 kali, pengetehuan yang kurang berisiko meningkatkan 3,083 kali mengalami kejadian anemia pada remaja putri. Perlunya peningkatan pengetahuan dengan penyebaran informasi atau penyuluhan tentang kesehatan reproduksi, khususnya tentang anemia pada remaja putri dan penyajian menu seimbang cukup Fe untuk mencegah kejadian anemia baik dengan status gizi kurang atau berlebih.

\section{Referensi}

Almatsier, Sunita, 2001, Prinsip Dasar Ilmu Gizi, Gramedia Pustaka Utama, Jakarta

Arisman, 2010, Buku Ajar Ilmu Gizi dalam Daur Kehidupan, EGC, Jakarta

Badan Litbangdepkes RI, 2008, Riset Kesehatan Dasar (Riskesdas), Tersedia (http://www.scribd.com/doc/31834110/indonesia-Riskesdas-2007) [8 Juli 2010]

Cunningham, F, Gary, Diterjemahkan oleh Joko Suyono, 1995, Obstetri WilliamsEdisi 18, Penerbit Buku Kedokteran EGC, Jakarta

Departemen Gizi dan Kesehatan Masyarakat, FKUI, 2009, Gizi dan Kesehatan Masyarakat, Rajawali Pers, Jakarta

Depkes RI, 2003, Program Penanggulangan Anemia Gizi Pada Wanita Usia Subur (WUS), Ditjen Gizi Masyarakat,Jakarta

Depkes RI, 2001, Rencana Strategis Nasional Making Pregnancy Safer (MPS) di Indonesia 2001-2010, Dirjend Bina Kesmas, Jakarta

Dieny, Fithra Fillah, 2014, Permasalahan Gizi pada Remaja Putri, Geraha Ilmu, Yogjakarta

Direktorat Jenderal Bina Kesehatan Masyarakat Depkes RI, 2008, Program Penanggulangan Anemia Gizi

Pada Wanita Usia Subur (WUS), Depkes, Jakarta 
Direktorat Jenderal Bina Kesehatan Masyarakat Depkes RI,, 2008, Gizi dalam Angka, Depkes RI, Jakarta

Jones, Derek Llewellin, 2005, Setiap Wanita, Delapratasa, Jakarta

Gunatmaningsih, Dian, 2007, Faktor-Faktor yang Berhubungan dengan Kejadian Anemia pada Remaja Putri, [online]. Tersedia (http://diangunatmaningsih.com/2007/05/15/faktor-faktor yang berhubungan dengan kejadian anemia pada remaja putri/) [05 April 2016]

Guyton dan Hall, 2001, Fisiologi Kedokteran, Diterjemahkan oleh Petrus Adriyanto, EGC, Jakarta

Hapzah; Ramlah Yulita, 2012, Hubungan Tingkat Pengetahuan Dan Status Gizi Terhadap Kejadian Anemia Remaja Putri Pada Siswi Kelas III Di SMAN 1 Tinambung Kabupaten Polewali Mandar, [Online], Tersedia (http://jurnalmediagizipangan.files.wordpress.com) [12 Maret 2016]

Isniati, 2007, Efek Suplementasi Tablet Fe + Obat Cacing terhadap Kadar Hemoglobin Remaja yang Anemia di Pondok Pesantren Tarbiyah IV Angkat Cadung Tahun 2008 [online]. Tersedia (http://ffarmasi.unand.ac.id/) [17 Juni 2016]

Malaria, ...2008, Malaria, [online]. Tersedia (http://3rrosists.com/medical/) [26 Juni 2010]

Manuaba, 2010, Ilmu Kebidanan Penyakit Kandungan Dan Keluarga Berencana, Penerbit Buku Kedokteran EGC, Jakarta

Martini, M. (2015). Faktor - faktor yang berhubungan dengan kejadian anemia pada remaja putri di MAN 1 Metro. Jurnal Kesehatan Metro Sai Wawai. 8(1), 1-7, http://dx.doi.org/10.26630/jkm.v8i1.162.g154.

Pedoman, ...2008, Pedoman Anemia, [online]. Tersedia (http://www.gizi.net/) [26 Juni 2016]

Soedjatmiko, 2010, Anemia Pengaruhi Kecerdasan, [Online]. Tersedia(http://www.preventionindonesia.com) [ 28 Juli 2016]

Supariasa, I Dewa Nyoman; Bakri, Bachyar; Fajar, Ibnu, 2004, Penilaian Status Gizi, Penerbit Buku Kedokteran EGC, Jakarta

Tarwoto, Wasnidar, 2007, Buku Saku Anemia Pada Ibu Hamil, Jakarta: Trans Info Medika

Tarwoto, Wartonah, 2008, Keperawatan Medikal Bedah Gangguan Sistem Hematologi, Jakarta: TIM

Weliyati, W., \& Riyanto, R. (2012). Faktor terjadinya anemia pada remaja putri di SMA Negeri kota Metro. Jurnal Kesehatan Metro Sai Wawai. 5(2), 28-36. http://dx.doi.org/10.26630/jkm.v5i2.1429.g932.

WHO, 2000, Suplementasi Iron Zin Antisipasi Anemia Remaja Putri [Online]. (Tersedia http://www.gizinet.com). [11 Mei 2016]

WHO, 2008, Worldwide Prevalence of Anaemia 1993-2005,[Online], Tersedia, (http://whqlibdoc.who.int) [3 Maret 2016]

Winkjosastro, H, 2008, Ilmu Kandungan, Yayasan Bina Pustaka Sarwono Prawirohardjo, Jakarta 